\title{
Effect of various Iranian native medicinal herbs or spices on in vitro ruminal disappearance of lucerne hay
}

H. Jahani-Azizabadi ${ }^{1}$, M. Danesh Mesgaran ${ }^{1}$, A.R. Vakili ${ }^{1}$, K. Rezayazdi ${ }^{2}$, A.R. Heravi Mousavi ${ }^{1}$

${ }^{1}$ Department of Animal Science, Excellence Center for Animal Science, Faculty of Agriculture, Ferdowsi University of Mashhad, P. O. Box 91775-1163., Mashhad, Khorasan Razavi, Islamic Republic of Iran

${ }^{2}$ Department of Animal Science, Faculty of Agriculture, University of Tehran, Karaj, Tehran, Islamic Republic of Iran

Email:jahani_hossein@yahoo.com

Introduction Recently, some studies have been conducted to determine the effects of medicinal herbs and spices on rumen microbial fermentation and nutrient disappearance (Busquet et al., 2006; Hart et al., 2008). However, a wide range of different results have been obtained when various medicinal herbs and spices have been added to different feed sources. The aim of the present study was to determine the effect of various Iranian native medicinal herbs or spices on in vitro disappearance of dry matter (DM), crude protein (CP) and neutral detergent fibre (NDF) of lucerne hay incubated with buffered rumen fluid.

Material and methods In vitro incubation was carried out as proposed by Menke and Steingass (1986). Approximately $300 \mathrm{mg}$ of dried and ground (through $2 \mathrm{~mm}$ screen) lucerne hay (control, NDF $=537$ and $\mathrm{CP}=150 \mathrm{~g} / \mathrm{kg} \mathrm{DM}$ ) or lucerne hay plus $18 \mathrm{mg}$ DM of either garlic, nutmeg, cinnamon, cumin, or rosemary were placed in $100 \mathrm{ml}$ glass syringes (5 replicates per each sample). Each syringe contained $40 \mathrm{ml}$ of buffered rumen fluid (ratio of buffer to rumen fluid, 2:1). Rumen fluid was obtained from three adult ruminally fistulated sheep $(49.5 \pm 2.5 \mathrm{~kg}$, body weight), before their morning feed; the rumen fluid was immediately strained through four layers of cheesecloth. Syringes were incubated under a $\mathrm{CO}_{2}$ atmosphere at $38.5^{\circ} \mathrm{C}$. After $24 \mathrm{~h}$ of the incubation, the syringe contents were filtered $\left(48 \mu \mathrm{m}\right.$ pore size) and residues were dried at $60{ }^{\circ} \mathrm{C}$ for $48 \mathrm{~h}$. Dry matter, CP and NDF concentrations of the residues were determined. Data were analysed using SAS (V. 9/1) and the Dennett's test used to compare the means $(\mathrm{P}<0.05)$.

Results The effect of medicinal herbs and spices on in vitro DM, CP and NDF disappearances of lucerne hay are shown in Table 1. Results of the present study indicated that turmeric and garlic caused a significant $(\mathrm{P}<0.05)$ increase in $\mathrm{DM}$ disappearance of lucerne hay. Under the conditions of the present study, medicinal herbs and spices caused also a significant $(\mathrm{P}<0.05)$ increase in the ruminal disappearances from lucerne hay, of $\mathrm{CP}$ and also, with the exception of rosemary, NDF.

Table 1 In vitro disappearance of dry matter, crude protein and neutral detergent fibre from lucerne hay, alone (control) or with Iranian native herbs or spices, following $24 \mathrm{~h}$ incubation with buffered rumen fluid

\begin{tabular}{llll}
\hline \hline \multirow{2}{*}{ Treatments } & Nutrients & & \\
\cline { 2 - 4 } & Dry matter & Crude protein & Neutral detergent fibre \\
\hline Lucerne hay (control) & 0.542 & 0.617 & 0.369 \\
Lucerne hay + Garlic & $0.603 *$ & $0.696^{*}$ & $0.533^{*}$ \\
Lucerne hay + Nutmeg & 0.572 & $0.720^{*}$ & $0.468^{*}$ \\
Lucerne hay + Cinnamon & 0.574 & $0.722^{*}$ & $0.471^{*}$ \\
Lucerne hay + Cumin & 0.584 & $0.677^{*}$ & $0.452^{*}$ \\
Lucerne hay + Turmeric & $0.623^{*}$ & $0.756^{*}$ & $0.489^{*}$ \\
Lucerne hay + Rosemary & 0.556 & $0.705^{*}$ & 0.417 \\
s.e.m & 0.003 & 0.002 & 0.004 \\
\hline \hline
\end{tabular}

In each column an asterisk $(*)$ indicates $\mathrm{P}<0.05$ compared with the control using Dennett's test.

Conclusions Results suggested that the medicinal herbs or spices used under the experimental conditions of this study (24h in vitro incubation) might alter ruminal disappearance of the lucerne hay nutrients. It was previously demonstrated that some medicinal herbs or spices may improve the cellulolytic and proteolytic activities of rumen microbiota (Khan and Chaudhry, 2008). These natural additives have the potential to alter the ruminal digestibility of ruminant feeds when used at appropriate concentrations. However, there is a need to test these herbs and spices under in vivo conditions using a wide rage of different feedstuffs.

\section{References}

Busquet, M., Calsamiglia, S., Ferret, A. and Kamel, C. 2006. Journal of Dairy Science. 89, 761-771. Hart, K.J., Yáñez-Ruiz, D.R., Duval, S.M., McEwan, N.R. and Newbold, C.J. 2008. Animal Feed Science and Technology. $147,8-35$.

Khan, M.M.H. and. Chaudhry A. S. 2008. Proceedings of the British Society of Animal Science. p 37.

Menke, K.H. and Steingass, H. 1988. Animal Research Development. 28, 7-55 